\title{
Migrant Remittances and their Impact on the Economic Development of the Baltic States
}

\author{
Gordon Rausser ${ }^{\mathrm{A}}$, Wadim Strielkowski ${ }^{\mathrm{A}^{*}}$, Yuriy Bilan ${ }^{\mathrm{B}}$, Yuliia Tsevukh ${ }^{\mathrm{C}}$ \\ Received: March 28, 2018 | Revised: June 13, 2018 | Accepted: June 25, 2018 \\ DOI: $10.5937 / g p 22-16988$
}

\begin{abstract}
This paper studies the determinants of international migration and remittances in the Baltic States (represented hereinafter by Lithuania, Latvia, and Estonia). The research reveals a critical view on migrant remittances in terms of macroeconomic development and social conditions in the society of each country involved into our research. In order to investigate and to demonstrate the impact of migrant remittances on GDP and consumption compared with current account balance, minimal wages, and foreign direct investment in the Baltic countries, econometric modeling based on the data of Eurostat, World Bank, and the National banks of the Baltic States has been employed. The results of this research clearly demonstrate that remittances sent by the migrants have high and positive impact on economic development in Lithuania, Latvia, and Estonia. Moreover, the findings stemming from this study confirm that minimum wages in the Latvia and Lithuania are far more important determinants of economic development than remittances.
\end{abstract}

Keywords: international migration; remittances; labor market; econometric modeling; Baltic States

\section{Introduction}

Modern day international migration is considered to be a global phenomenon and one of the key components of population change in the European Union (EU). Since the EU Eastern Enlargement in 2004, European labor markets have been facing processes including the change and development in migration waves and the free movement of workers. Although the contemporary migrations are a worldwide phenomenon, the European Union currently remains one of the main destinations for both low-skilled and high-skilled labor force.

The Baltic States (referred to as such hereinafter and comprising Lithuania, Latvia, and Estonia) are actively involved in migration processes in the EU with mi- gration being on the rise after the restoration of their independence (Štreimikienè et al., 2016). Having chosen the pathway to full European integration process, the Baltic States faced many economic and political issues (many of them related to the EU Enlargement) which uncovered the weaknesses of their financial systems, economic policies, and social security systems. Nevertheless, after the EU Accession in 2004, the Baltic economies demonstrated rapid economic growth: in 2006, the real GDP growth rate in Latvia was $11.9 \%$, in Estonia it constituted $10.3 \%$, and in Lithuania it was recorded to be at 7.4\% (Trošt \& Bojnec, 2016). But the foundations of the Baltic economies were not stable, and the financial and economic crisis clearly demon-

A Department of Agricultural and Resource Economics, University of California, Berkeley, Giannini Hall, Berkeley, CA 94720, United States

B Centre of Applied Economic Research, Faculty of Management and Economics, Tomas Bata University in Zlin, Mostní 5139, 760 01, Zlin, Czech Republic

c Department of World Economy and International Economic Relations, Odessa National I.I. Mechnikov University, Dvoryanskaya str. 2, 65082 Odessa, Ukraine

* Corresponding Author. E-mail: strielkowski@berkeley.edu 
strated their weaknesses. Cheap foreign capital was used for consumption purposes, not for investment in production and other fields for development. Somewhat similar situation occurred with the remittances sent by the migrants. Households used that money to buy long-term and short-term goods, real estate, and other non-durable goods and services. Hazans and Philips (2011) showed that $63.4 \%$ of return migrants in the Baltic countries used foreign income for everyday needs. In most of the cases, migrant remittances are not invested in economic development that might also lead to negative outcomes. In the same time, $\mathrm{Ka}$ hanec and Zimmermann (2011) noted the positive role of remittances in improving the standards of living in
Estonia - households experienced less financial difficulties if their family members worked abroad. Remittances represent readily available and affordable money which increased globally changing the standards of living of the households and making impact on social and economic situation in the countries of origin. Thence, it is considered highly important to study the role of migrant remittances and their impact on economic development in the Baltic States.

This paper is organized as follows: Section 2 provides a literature review on migration and remittances. Section 3 outlines the empirical model, presents its main results and discusses the outcomes. Section 4 concludes with main implications and discussions.

\section{Literature review: migration and remittances}

An increasing interest in using the potential of migrant remittances for a social-economic development during the last decade led to an upsurge of scientific publications and studies (see e.g. Agunias, 2006; Chami et al., 2008; Ghosh, 2006; OECD, 2006; Rapoport \& Docque, 2006; World Bank, 2013; World Bank, 2015; Mikalauskiene et al., 2017; or JędrzejowskaSchiffauer and Schiffauer 2017). One of the common features of these studies was that remittances were found to be beneficial for the economy. As a matter of fact, these studies, described an influence of cash remittances on the countries of origins where the migrants originated from and considered them as a relatively stable source of a foreign currency as well as an alternative net of security for the poor (Mishra and Singhania, 2014).

According to the assessment of the World Bank (2016), in 2015 a number of international migrants in Europe has reached 76 million making up nearly two thirds of all international, migrants. A number of international migrants increased even more from 2010 to 2013 . In Romania, it increased by $4.8 \%$, in Turkey by $2.8 \%$, and Hungary by $2.7 \%$. The most significant outflows of migrants were recorder in Lithuania, Latvia, and Bosnia and Herzegovina.

There are different points of view about the impact and the outcomes of remittances. On the one hand, they may have a positive effect on social and economic situation, help to reduce poverty, and stimulate consumer demand; often they represent a significant factor to optimize the balance of payments in many economies (Angioloni et al., 2017). Remittances are one of the most important factors of international migration, providing financial support to the families of migrants remaining in the country of origin as one of the key instruments of economic development. Remittances are one of "survival strategies" that help to cover current expenses of households (see e.g. Cohen, 2005; Strielkowski \& Weyskrabova, 2014; Davis, 2016).

On the other hand, some studies draw attention to the potential negative impact of remittances on the real exchange rate and the economy in the situation similar to the "Dutch disease": some economies receive extra financial resources, becoming dependent on them (Stojanov et al., 2011). The currency sent to the country by migrants is spent on current consumption, which may be destructive for the economy and enhance income inequality in society between households that receive that money and those that do not have these revenues. In addition, remittances may cause inflation and push further migration (Cohen, 2005).

Massey $(1993 ; 2003)$ views the money that migrants transferred or brought home as the most obvious contribution of migrants to the economy of the country of origin. Ukrainian researchers point to the emergence of "migration capital," which is a separate component of international capital markets and a significant part of the domestic capital market in Ukraine (Rausser \& Strielkowski, 2013). Levitt (1998) stays that remittance is not only about economy and proposes to provide the term "social remittance" to describe noneconomic transfers such as ideas, practices, experiences and other "difficult-to-measure" assets from migrants to households or communities in the origin countries. Unlike the money remittances, which is sent in one way direction, social remittances circulate when migrants return or visit their native country, when migrants are visited by their family members or friends, when migrants communicate with their communities. Continuing the studies mentioned above, some researchers propose to include cultural element in definition of social remittances and identify the negative and positive impacts of this type of remittanc- 
es (Stojanov et al., 2011). At the same time, being an important part of migration-related process, social remittances are not well studied; there is no measurable indicators for making a reliable analysis with strong conclusions. In our paper, we do not take into account social remittances but just mention them as one of the underlying factors. Moreover, it has to be stressed that informal remittances are also not taken into account due to the scope and the focus of our paper. This is regrettable, since the share of the informal remittances in the amount of total remittances might be very important from the policy perspectives (Chvátalová, 2016). Moreover, one should explore the significant economic impact of migration as a result of receiving remittances by the country of origin. In 2014, the worldwide remittance amounted at $\$ 580$ billion which was 3.5\% higher than in 2013. Developing countries received $73.62 \%$ of all the remittance or $\$ 427$ billion (World Bank, 2015). In recent years, migrant remittances have become a relatively stable source of funding; during the financial crisis, these funds represented more stable amounts of revenues than other financial inflows (Migration and Remittances Factbook, 2016). Being on the rise globally, remittances yielded smother dynamics than investments inflows. Over the last ten years we could observe fewer fluctuations in remittance flows than in FDI. In 2009 during the financial crisis the worldwide remittance inflows were decreased 6.5\% (and amounted \$421.5 billion) compared with the previous year, while foreign direct investment decreased by $20 \%$ in 2009 . Besides, FDI to developing countries were unstable having fluctuations from $4.6 \%$ to $36.4 \%$. At the same time, remittances have constantly grown to these countries since 2010 (UNCTAD, 2015).
In 2014 alone, about $50 \%$ of all the remittance inflows went to 9 countries: China, Arab Republic of Egypt, France, Germany, India, Mexico, Nigeria, Pakistan, Philippines. Nevertheless, another top 9 countries were dependent on remittance the most in 2014. The ratio of remittance to GDP was more than $20 \%$ in the countries: Bermuda 23.8\%, The Gambia $22.4 \%$, Haiti 22.4\%, Kyrgyz Republic 30.3\%, Liberia 26.1\%, Moldova $26.1 \%$, Nepal 29.9\%, Tonga $26.3 \%$, and Tajikistan 41.7\% (World Bank, 2015).

International migration and remittance in the Baltic countries are of a particular interest for a thorough analysis as far as they are deeply involved in the process of international migration. In addition, these countries went through a difficult process of changing their economic system, having chosen the path of economic integration as a part of the European Union and having performed the integration process into the Eurozone relatively fast. These stages were reflected in economic development but at the same time uncovered structural weaknesses of the Baltic economies. Migration flows and remittance also reacted on the EU accession and other processes.

Over the past 10 years, one could observe considerable citizens' outflows from Estonia, Latvia, and Lithuania compared to the amount of population (see Figure 1). The main reasons of this trend are the issues in the financial sector, the low level of welfare, high unemployment rate, slow growth of the labor market, high inflation, the accession to the Eurozone, as well as other relatively less important factors (Melnikas, 2008). At the same time, Kaczmarczyk and Okolski (2008) state that the official statistics of emigration does not represent the real situation as far as many people from such countries as Poland go to work

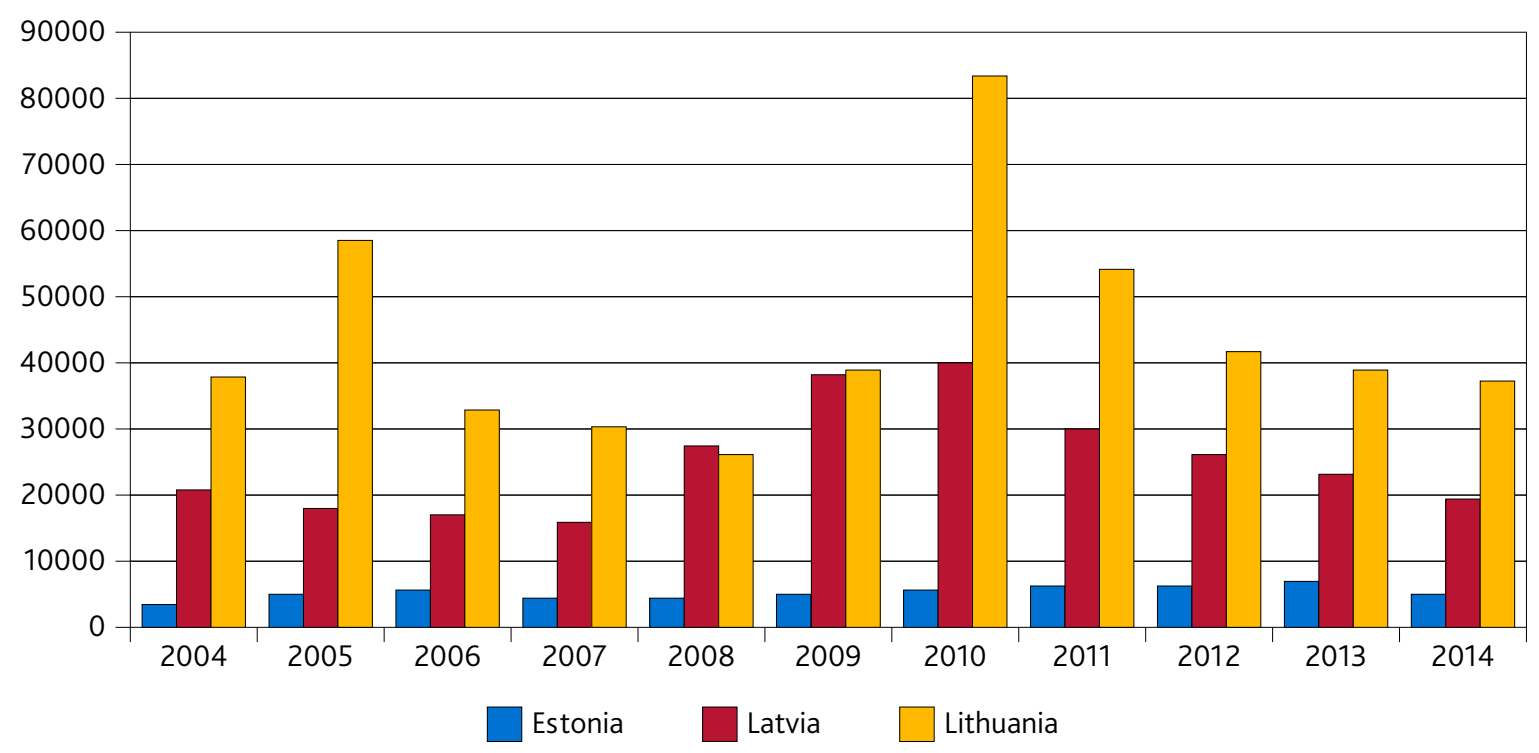

Figure 1. Emigration from the Baltic countries in 2004 - 2014

Source: Eurostat (2015) 
abroad without reporting their incomes in their home countries (i.e. without deregistration).

Similar to many other countries, migrants from the Baltic States seek regions with higher level of income and higher standards of living. In order to show the comparable shares of emigrants by Baltic countries of origin, one can use the 2014 data collected by Eurostat (2015). In 2015, about $88 \%$ of all outgoing emigrants from Estonia, 61\% of all emigrants from Latvia, and 92\% of all outgoing emigrants from Lithuania moved out to establish their permanent residence in the EU-15 countries (Eurostat, 2015). Among them, 5856 Estonians migrated to Finland, 624 to Norway, 547 to Sweden, 209 to Denmark, 148 to Belgium, and 125 to Ireland. Latvians went to the United Kingdom (6268 persons), Germany (2066), Norway (1294), Ireland (1177), Netherlands (623), Sweden (599), and Finland (198). Lithuanians' priority directions were United Kingdom (17929 persons), Norway (5420), Ireland (1766), Denmark (1448), Sweden (1155), Netherlands (858), Italy (368), and Belgium (273). For comparison, the ten main destination countries for emigrants from the Baltic States had several times higher GDP per capita and minimum wages than the Baltic States. In 2014 the highest GDP per capita was in Norway (73,2 thousand euro per capita), Denmark (47 thousand), and Sweden (44,6 thousand), while in Estonia, Latvia and Lithuania this index was 15 thousand euro per capita, 11,8 thousand, and 12,5 thousand respectively (Eurostat, 2015).

Due to the fact that employees' income depends on the volume of minimum wages to a certain extent, we consider it to be an important indicator of making migration decisions and to moving from the sending country (based on the neoclassical theory of migration, "push-pull" theory, and available statistical data) to the receiving country. In 2014, the minimum wage in Estonia was $€ 355$ euro a month, in Latvia €289,62, and in Lithuania $€ 289,62$ (e.g. in the United Kingdom, one of the main regions of Baltic migrants, this index was $€ 1251,05$ per month) (Eurostat, 2015).

According to the officially recorded statistics of migrant remittances to the Baltic States, there was an obvious increase in these inflows after joining the $\mathrm{EU}$ in 2004 for all the three countries. More rapid growth in remittance's dynamics was in Lithuania, which has more citizens leaving the country (Table 1). During the financial crisis, remittances inflows decreased by $15.5 \%$ in Estonia, $1.7 \%$ in Latvia, and $20.8 \%$ in Lithuania. But the positive dynamics was renewed again in 2010.

European migration and remittances are studied with help of qualitative and quantitative empirical analysis in terms of microeconomic and macroeconomic perspective. In terms of international migration analysis, econometric modeling is an important and handy tool for exploring whether there is impact, and to what extent, of various macroeconomic indicators on the migration inflows and outflows. Additionally, econometric models allow evaluating the macroeconomic impact of migrant remittances on economic growth and development.

In an early study of Paas et al. (2003), the authors compared flexibility of wages between Estonia, Latvia, Lithuania, and the EU countries before the EU Accession and analyzed the future consequences of international labor migration for the EU labour market. It was assumed that the future effects of the Baltics integration would be insignificant for the EU labour market because of the small population of the Baltic countries. In the later studies (Hazans \& Philips, 2011; Kahanec \& Zimmermann, 2011) the authors investigated how migrant remittances are used in the national economy of the Baltic countries. Analyzing remittances during the economic crisis, Dietz (2009) predicted their decline in the Central and Eastern Europe. The author assumed the negative tendencies in the national labour markets such as an increase in unemployment rates in case of migrants' returning. Hazans (2003) reported the positive connection between high unemployment rate and migration outflows. At the same time, outmigration was discouraged by high wages. In one of the recent research studies on the topic (Hazans \& Philips, 2011), the factors of international migration between the two groups of countries: Estonia, Lithuania, Latvia, Poland, Hungary, Slovenia and the EU-15 were investigated and proved that the difference in the minimum wages is one of the main factor of legal emigration from the first group to another.

Strielkowski and Sanderson (2013) presented somewhat different scope of the research than the other papers mentioned above. They investigated the process of labour migration in construction sectors from Ukraine to the Czech Republic and concluded that there is no loss of human capital and braindrain from Ukraine, and Ukrainian immigrants tend

Table 1. Migrant remittances inflows to the Baltic states in $2004-2014$ (millions, \$)

\begin{tabular}{|l|c|c|c|c|c|c|c|c|c|c|c|}
\hline Country & 2004 & 2005 & 2006 & 2007 & 2008 & 2009 & 2010 & 2011 & 2012 & 2013 & 2014 \\
\hline Estonia & 167 & 264 & 402 & 411 & 362 & 306 & 320 & 407 & 411 & 536 & 523 \\
\hline Latvia & 230 & 381 & 482 & 552 & 601 & 591 & 616 & 697 & 732 & 764 & 793 \\
\hline Lithuania & 325 & 745 & 994 & 1433 & 1565 & 1239 & 1673 & 1954 & 1508 & 2060 & 2113 \\
\hline
\end{tabular}

Source: The World Bank (2015) 
to work in the same sector of the Czech economy. In some recent papers on the topic (e.g. Martinez et al., 2015), based on institutional theory and TCE-theory, it was proved that higher levels of economic informality decrease venture funding, while remittances increase venture funding availability in. The OLS model was made for developing countries (Cambodia, Namibia, Sri Lanka, Uganda, Ukraine, Vietnam, etc.). There- fore, one cannot consider applying it to the free-market economies. Kahanec and Zaitseva (2009) and Kahanec et al. (2009) demonstrated that the number of emigrants depends on the economic and demographic situation in the country. Furthermore, the authors also described the most significant macroeconomic factors that influence migration in Estonia, Latvia, Lithuania, Poland, Hungary, and Slovenia.

\section{Empirical model and its results}

In our empirical model presented in this section, we turned to econometric modeling approach which allows us to conduct a time-series, panel data, and cointegration analysis. It is appropriate to use time-series in case when the number of observations for one object is more than 25-30, therefore, we can make valuable conclusions about relations between economic variables. In order to make the most appropriate regression model, it is important to estimate the quality and stability of the models and their coefficients based on the theoretical and methodological foundations with the following parameters: $\beta$ standardized parameters, Student's test (t-statistics), Fisher's test (Fstatistics), coefficient of determination $\mathrm{R}_{2}$ and adjusted coefficient of determination, Durbin-Watson test, CUSUM-test, test for multicollinearity and autocorrelation, and other tests.

Our model is based on similar models that can be found in Kahanec at al. (2009), Kahanec and Zaitseva (2009) or Kliček and Lončar (2016). All these models investigate the impact of total consumption, current account balance, FDI, and migrant transfers on GDP. Moreover, the impact of current account balance, FDI, total wages, total taxes, and migrant transfers on consumption is often investigated in the same fashion. It can be shown that the impact of remittances on economic development was investigated in previous research using the category called "consumption". The direct and indirect effect of remittance on economic growth through consumption was argued by Barajas et al. (2009), Giuliano and Ruiz-Arranz (2009), Ratha (2005), or Meyer and Shera (2017). For instance, Ratha (2005) points out the "consumption-smoothing" effect of remittance and considers them as a factor of sustainable economic growth. Barajas et al. (2009) researched the impact of remittances on consumption and other economic indicators and compared remittance with foreign direct investment, considering them as a possible way to finance consumption.

Meyer and Shera (2017) argue that remittances have positive impact on economic growth "through consumption savings, or investment". They investigat- ed the impact of consumption, remittance, FDI and other macroeconomic indicators on GDP growth and concluded that remittance were the most important factor for Albania during the researched period from 1999 to 2013.

In our present research, we modified these two models in order to investigate how minimum wages, current account balance, FDI, and migrant transfers influence GDP and consumption. Based on the topic of the research, we conduct a thorough analysis for the selected region, namely for the Baltic States. In the present paper, we are making the following assumption: migrant remittances have a significant impact on the macroeconomic indicators (GDP and consumption) in Estonia, Latvia, and Lithuania.

In order to identify the consequences of migration on the economic development for the countries of origin, we chose the Baltic countries as an object of the study. This gives an opportunity to notice conveniently and to evaluate the effects of labour migration for national economies, as well as to point out those factors that had the most significant influence on the socio-economic development. In the regression, we use GDP, our dependent variables, as an integral determinant of long-term economic development of the country in general and consumption as a determinant of a household wealth. One should underline that pointing out of these variables as dependent ones is based on the necessity of evaluation of the degree of influence of a labour migration both on the dynamics of economic growth in general and on the consideration of a fact that migrant remittances may stimulate inflation of demand and lead to an inequality of incomes. The choice of independent variables in the model was predetermined by the following assumptions:

- Migrant remittances (Remit). Because remittances play an important role for the households particularly and the economy in general, we tend to evaluate their impact on the chosen macroeconomic indicators. As the results of studies show, migrant remittances can stimulate the rise of internal demand, which brings along economic and socioeconomic development with a multiplication effect; 
facilitate structural reconstruction of economy and employment.

- Minimum wage (MinWAGE): Based on the macroeconomic theory and researches of Sabia (2015) and other authors, we assume that there is the relationship between minimum wages, GDP, and consumption in the following way: if the government increases minimum wages, the workers can spend more (therefore, consumption raises). If the consumption increases, it has a positive effect on GDP growth. Although there is theoretical assumption that a minimum-wage increase might lead to the employment reduction in the labor market, we do not take it into consideration. In our study, we take minimum wages expressed in Euros from the official statistical websites only, and it is the national wages in each country, not the differences between the country of origin and the country of emigration.

- Foreign direct investments (FDI): in case of the Baltic States, inflows of foreign direct investment played an important role on their way from socialism to countries in transition and then to free-market economy. But over the last years one can observe significant fluctuations of FDI to the host countries, while remittances have more stable dynamics. Taking into account the economic situation and volume of emigration from the Baltic States, it is not surprising that remittances' inflows have become higher than FDI (e.g. in 2014 FDI amounted $\$ 507$ million, while remittances were \$523 million). Thence, in our empirical model we also try to evaluate and compare the impact of FDI and remittances as the key financial flows.

- The current account balance (CA): being a relatively stable source of foreign currency remittances contribute to the balance of the current accounts and play an important role in supporting macroeconomic stability in recipient countries that suffered from a conjuncture drop or macroeconomic shocks. At the same time, an increased dependence of the national economy from the remittances may negatively influence the general economy's resilience in front of financial and economic crisis from abroad and increase the internal volatility of the business cycle. One can deduce that we use current account as an independent variable and it might pose a problem, since workers' remittances constitute a part of current transfers in a national economy, which in turn constitute a part of the current account. That is why we evaluated the models with the variable "current account" and variable "current account minus compensation of employees and migrant transfers" separately. The results of the evaluated models demonstrated minor dif- ference between them and do not change the outcomes (the significance of $t$-statistics is in the same measures Therefore, we introduce the models with the variable "current account".

It should be noted that the influence of labour migration on the state of national economies may be investigated considering a much higher number of factors, however the volume of analyzed data on the Baltic countries, that is represented in an open access is limited and we concentrate on the four factors in the following empirical analysis.

We build two regression models in order to determine the impact of migrant remittances and other indicators on consumption and GDP in the Baltic countries. We use time series for the data taken from Q1 2005 to Q1 2015, with an interval of 1 quarter. There are 41 observations for each country. All calculations are performed with help of Gretl 1.9.6 software. We use the official statistics from statistical database of the International Monetary Fund, Eurostat, and the national banks of Estonia, Latvia, and Lithuania. Considering all of the above, our two basic models have the following general view:

$$
\begin{aligned}
& G D P t=\alpha+\beta_{1} C A+\beta_{2} F D I+\beta_{3} R E M I T+ \\
& \beta_{4} M i n W A G E+v_{t}(1) \\
& C O N S_{t}=\alpha+\beta_{1} C A+\beta_{2} F D I+\beta_{3} R E M I T+ \\
& \beta_{4} M I N W A G E+v_{t}(2)
\end{aligned}
$$

where

- GDP - GDP measured in millions of Euro,

- CONS - total consumption measured in millions of Euro;

- CA - current account balance measured in millions of Euro;

- FDI - foreign direct investment measured in millions of Euro;

- REMIT - compensation of employees and migrant transfers measured in millions of Euro;

- MinWAGE - minimal wages measured in Euro;

- $t$ - time variable;

- $v_{t}$-standard error term.

Table 2. Results of multicollinearity test for the regression models

\begin{tabular}{|l|c|c|c|}
\hline Variables & Estonia & Latvia & Lithuania \\
\hline & VIF & VIF & VIF \\
\hline CA & 5,060 & 1,870 & 1,440 \\
\hline FDI & 2,033 & 1,249 & 1,168 \\
\hline Remit & 2,889 & 1,651 & 2,033 \\
\hline MinWage & 4,249 & 2,342 & 2,371 \\
\hline
\end{tabular}

Source: Own results 
Table 3. Evaluation results of the regression model 1 for the Baltic States

\begin{tabular}{|c|c|c|c|}
\hline \multicolumn{4}{|c|}{ Endogenous variable: GDP } \\
\hline \multirow{2}{*}{$\begin{array}{l}\text { Exogenous } \\
\text { variables, } \\
\text { parameters }\end{array}$} & Estonia & Latvia & Lithuania \\
\hline & $\begin{array}{l}\text { Coefficient } \\
\text { (t-statistics) }\end{array}$ & $\begin{array}{l}\text { Coefficient } \\
\text { (t-statistics) }\end{array}$ & $\begin{array}{c}\text { Coefficient } \\
\text { (t-statistics) }\end{array}$ \\
\hline Const & $\begin{array}{c}363,839 \\
(1,399)\end{array}$ & $\begin{array}{c}641,038 \\
(2,681)\end{array}$ & $\begin{array}{l}521,191 \\
(0,878)\end{array}$ \\
\hline CA & $\begin{array}{c}-0,159 \\
(-0,785)\end{array}$ & $\begin{array}{l}-0,379 \\
(-1,789)\end{array}$ & $\begin{array}{l}-0,687 \\
(-3,11)\end{array}$ \\
\hline FDI & $\begin{array}{l}2,445 \\
(2,190)\end{array}$ & $\begin{array}{c}0,323 \\
(0,816)\end{array}$ & $\begin{array}{c}-2,5 \\
(-2,197)\end{array}$ \\
\hline REMIT & $\begin{array}{r}18,311 \\
(5,052) \\
\end{array}$ & $\begin{array}{c}1,472 \\
(8,487) \\
\end{array}$ & $\begin{array}{c}7,912 \\
(4,237) \\
\end{array}$ \\
\hline MinWAGE & $\begin{array}{c}7,356 \\
(6,945)\end{array}$ & $\begin{array}{c}4,65 \\
(3,509)\end{array}$ & $\begin{array}{c}17,358 \\
(5,598)\end{array}$ \\
\hline $\mathrm{R}^{2}$ & 0,868 & 0,912 & 0,822 \\
\hline $\mathrm{R}^{2}$ adj. & 0,853 & 0,903 & 0,802 \\
\hline$F(4,36)$ & 58,97 & 93,784 & 41,584 \\
\hline DW & 2,537 & 1,646 & 2,077 \\
\hline
\end{tabular}

Note: $t$-statistics (in brackets);

Source: Own results

We construct our models with the help of the least square method for time series and evaluate them by applying the tests mentioned above. Each model is tested for multicollinearity and the results show there is no multicollinearity as far as VIF does not exceed 10 (Table 2).

We apply the two models for each Baltic country. Therefore, we obtain three evaluations of each model (Tables 3-4). The results of the regression model specified in (1) are represented in Table 3 that follows.

Statistical evaluation of the impact of migrant remittance and other macroeconomic factors on consumption obtained via the least square method are reported in Table 4.

Our estimations of the models specified in (1) and (2) confirm the fulfillment of all prerequisites of the least square method. Values of coefficient of determination $\mathrm{R} 2$ and adjusted coefficient of determination indicate good quality of the models and that they can be used for valuable economic conclusions. We evaluate t-statistics of the models comparing with t-criteria which is equal 2.04 for the level of significance equal 0.05 .

Therefore, this analysis allows us to make the following economic interpretation of the results of regression modeling for Estonia. We checked both models for multicollinearity and autocorrelation and did not find any signs of both.

In order to test the resulting models for stability, we apply CUSUM-test (95\% probability) that proves the model 1 is stable and the model 2 has fluctuations in 2008 which we connect with the negative economic
Table 4. Evaluation results of the regression model 2 for the Baltic States

\begin{tabular}{|c|c|c|c|}
\hline \multicolumn{4}{|c|}{ Endogenous variable: CONS } \\
\hline \multirow{2}{*}{$\begin{array}{l}\text { Exogenous } \\
\text { variables, } \\
\text { parameters }\end{array}$} & Estonia & Latvia & Lithuania \\
\hline & $\begin{array}{l}\text { Coefficient } \\
\text { (t-statistics) }\end{array}$ & $\begin{array}{c}\text { Coefficient } \\
\text { (t-statistics) }\end{array}$ & $\begin{array}{c}\text { Coefficient } \\
\text { (t-statistics) }\end{array}$ \\
\hline const & $\begin{array}{c}390,602 \\
(3,926)\end{array}$ & $\begin{array}{c}539,954 \\
(3,654)\end{array}$ & $\begin{array}{c}607,896 \\
(1,95)\end{array}$ \\
\hline CA & $\begin{array}{l}-0,254 \\
(-3,273)\end{array}$ & $\begin{array}{c}-0,457 \\
(-3,489)\end{array}$ & $\begin{array}{c}-0,402 \\
(-3,464)\end{array}$ \\
\hline FDI & $\begin{array}{c}1,074 \\
(2,516) \\
\end{array}$ & $\begin{array}{l}-0,004 \\
(0,107) \\
\end{array}$ & $\begin{array}{c}-1,429 \\
(-2,391)\end{array}$ \\
\hline REMIT & $\begin{array}{c}7,677 \\
(5,540)\end{array}$ & $\begin{array}{c}0,598 \\
(5,579)\end{array}$ & $\begin{array}{c}3,856 \\
(3,931)\end{array}$ \\
\hline MinWAGE & $\begin{array}{c}3,835 \\
(9,467)\end{array}$ & $\begin{array}{c}4,736 \\
(5,782) \\
\end{array}$ & $\begin{array}{l}11,883 \\
(7,295) \\
\end{array}$ \\
\hline $\mathrm{R}^{2}$ & 0,905 & 0,901 & 0,86 \\
\hline $\mathrm{R}^{2}$ adj. & 0,895 & 0,89 & 0,844 \\
\hline$F(4,36)$ & 86,466 & 81,888 & 55,204 \\
\hline DW & 2,43 & 1,67 & 1,96 \\
\hline
\end{tabular}

Note: -statistics (in brackets);

Source: Own results

situation in Estonian economy during the crisis. The current account balance of Estonia does not have effect on GDP, despite its immanent deficit, but have negative impact on consumption.

The results of the regression model 1 reveal that the remittances of Estonian migrants have statistically significant effect on GDP growth. The results of the model 2 show that there is also significant impact of these transfers on the growth of total consumption. If the rest of parameters stay constant, remittances cause GDP growth to 18.3 units and consumption growth to 7.7 units. The same observation can be applied to the increase of minimum wages that have a direct impact on GDP and consumption in Estonia.

Overall, it appears that in case of Baltic States, minimum wages constitute far more significant factor for economic development of Latvia and Lithuania than remittances. Estonia is the only country in which remittances have more significant impact on GDP and consumption than minimum wages. These results are quite important and therefore should be discussed in greater detail. First of all, there is no single theory that would explain the interdependence between remittances and GDP. Matuzeviciute and Butkus (2016) attempt to build a model that would estimate this interdependence for countries with various level of economic development but get mixed results.

Second, out results might come through as such due to the peculiarities of the econometric analysis and its results. When looking at the regression coefficients, remittances would surpass minimum wag- 
es in significance, however the whole picture changes when one looks at the elasticity coefficients (showing how the resulting variable would change if the given parameter's value is changed by $1 \%$ ). The coefficients of elasticity in all three Baltic States are quite high: in Estonia, the coefficient of elasticity of Remit variable is 0,343 and Min.wage variable is 0,499 . In Latvia and Lithuania, they are 0,624 and 0,214 and 0,397 and 0,527 respectively. There results mean that the minimum wage can also be significant for economic development in Estonia. The values of the coefficients of elasticity would yield a more realistic picture - they show that remittances and minimum wages are far more significant for economic development than the other two parameters.

Third, the high significance of remittances in Estonia can be explained in economic terms: it might be that Estonia is more dependent on remittance than other Baltic States due to its level of economic development (the value of Estonian GDP is lower, and the inflow of remittances can be felt at the households' micro-level and at the macro-level.

The impact of foreign direct investment on GDP growth and consumption has low significant impact. If the other parameters stay constant, FDI lead to GDP growth to 2.4 units and consumption growth to 1.07 units. That demonstrates that the inflow of foreign direct investment in Estonia has a less significant effect on the growth of GDP than migrant remittances.

Economic interpretation of the results of regression modeling for Latvia is the following: both models do not have multicollinearity and autocorrelation. CUSUM-test proves the model 2 is stable; the model 1 has insignificant deviations in the end of 2013 that we con- nect with fluctuations of current account and foreign direct investment;

According to our model, the current account balance has a negative impact on GDP (if negative balance of current account is increased, consumption is reduced by 0.46 units);

Migrant remittances and minimal wages of Latvians have the most significant impact on GDP growth and consumption. If the other factors of the models stay constant, an increase in remittances lead to GDP growth to 1.47 units and consumption to 0.6 units.

Our model yielded almost no significant effect of the inflow of FDI into the Latvian economy on the GDP growth. Migrant remittances have greater effect and can be called to be a factor of economic growth. However, they cannot stabilize the balance of payments and provide macroeconomic stability alone.

Based on the modeling, we make the following conclusions for Lithuania: both models do not have multicollinearity and autocorrelation. CUSUM-test proves the models 1 and 2 are stable. Migrant remittances and minimum wages of Lithuanians are statistically the most important factors of the GDP growth and consumption in Lithuania. An increase of migrant transfers leads to GDP and total consumption growth to 7.9 and 3.8 units, respectively (other things held constant). Therefore, the results confirm a crucial importance of the existing and future flows of remittance for economic development in Lithuania. Foreign direct investment has low negative impact on Lithuanian economy that may be connected with negative FDI balance in some periods. Current account balance has negative impact on GDP and consumption that is connected with its negative dynamics in long-term period.

\section{Conclusions and discussions}

Having chosen the pathway to the European integration and EU Membership, Estonia, Latvia, and Lithuania faced many issues related to the EU Accession. At the same time, after the EU accession happened, the Baltic economies yielded significant economic growth and development. Migration and remittances flows reacted immediately on the changed conditions, demonstrating fluctuations over the last eleven years.

Over the latest years, migration outflows from Lithuania, Latvia and Estonia demonstrated unprecedented amounts with might be explained by the economic recession during the financial crisis, high inflation, high unemployment, and difficult situation on the labor market. Nowadays, economic growth in the three Baltic States seems to be dependent on the amount and dynamics of migrant remittances. The statisti- cal data shows that Baltic emigrants mainly work in the UK, Ireland, Finland, Norway, and other European countries where the welfare and wages are much higher than in Estonia, Latvia and Lithuania. Remittances became relatively stable and cheap source of cash that allows migrants to help their family members who stayed in the countries of origin.

Moreover, it appears from our analysis that minimum wages in the Baltic countries constitute far more significant factor for economic development of Latvia and Lithuania than remittances. According to our results, Estonia is the only country with the remittances having more significant impact on GDP and consumption than those of minimum wages. Apart from the importance of remittances, this finding can be very important in explaining contributing factors to economic development of the Baltic States. 
Our empirical analysis indicated that international migration and remittances have significant impact on the economy of Baltic countries. Based on the overview of the research of other authors and our own econometric modeling, we showed positive economic impact of migrant remittances on economic development compared with other macroeconomic factors. Our results confirm that the economic growth in all three Baltic States is highly dependent on the volume and dynamics of migrant workers.

One of the main macroeconomic problems for the three countries is the negative current account balance in a long-term period that cannot be solved only with help of receiving remittances. It is very important to mention here and to discuss the existing government policies for remittances investment at the different levels of government in Baltic States. In all Baltic States, there is a plethora of government policies aiming at mobilising the human capital and financial resources accumulated by migrants. Since the emigration from the Baltic States is strongly correlated with the declining of economic opportunities, worsening of the economic situation, as well as deteriorating socio-economic conditions, migrant population is constantly evolving. The governments of the three Baltic State attempt to implement such initiatives as investment through remittances as well as the transferability of human capital, however these initiatives need precise data on migration patterns and migrant characteristics and are often unavailable. There is an urgent need to understand the characteristics and the needs of the Baltic migrants using the precise data.

The inflows of FDI are insufficient and do not have positive impact on GDP grows and consumption. Therefore, it seems to be crucial for the Baltic economies not only to attract but also to stimulate investment in economic development. The same is true for the migrant remittances: it is essential to stimulate investment of the currency in production and long-term social project that will improve welfare and development. The governments in the Baltic States should provide more balanced trade, budget, as well as fiscal policies.

\section{References}

Agunias, D.R. (2006). Remittances and Development: Trends, Impacts and Policy Options: A Review of the Literature. Washington, D.C.: Migration Policy Institute.

Angioloni, S., Kudabaev, Z., Ames, G.C.W., \& Wetzstein, M. (2018). Household allocation of microfinance credit in Kyrgyzstan. Post-Communist Economies, 30(1), 78-98. doi:10.1080/14631377.2017.1 361691

Chvátalová, I. (2016). Social policy in the European Union. Czech Journal of Social Sciences, Business and Economics, 5(1), 37-41. doi: 10.24984/cjssbe.2016.5.1.4

Gapen, M.T., Chami, R., Montiel, P., Barajas, A., \& Fullenkamp, C. (2009). Do Workers' Remittances Promote Economic Growth. IMF Working Papers, 09(153), 1. doi:10.5089/9781451873009.001

Chami, R., Barajas, A., Cosimano, T., Fullenkamp, C., Gapen, M., \& Montiel, P. (2008). Macroeconomic consequences of remittances (p. 259). Washington, DC: International Monetary Fund.

Cohen, J.H. (2005). Remittance outcomes and migration: Theoretical contests, real opportunities. Studies in Comparative International Development, 40(1), 88-112. doi:10.1007/bfo2686290

Davis, C.M. (2016). The Ukraine conflict, economic-military power balances and economic sanctions. Post-Communist Economies, 28(2), 167-198. doi:10.1080/14631377.2016.1139301
Dietz, B. (2009). Migration, remittances and the current economic crisis: Implications for Central and Eastern Europe (No. 42). Institut für Ost-und Südosteuropaforschung [Institute for East and Southeast European Studies].

Eurostat. (2015). Statistical Database. http://ec.europa. eu/eurostat/data/database.

Ghosh, B. (2006). Migrants' Remittances and Development: Myths, Rhetoric and Realities. Geneva: International Organization for Migration/The Hague, Process on Refugees and Migration.

Giuliano, P., \& Ruiz-Arranz, M. (2009). Remittances, financial development, and growth. Journal of Development Economics, 90(1), 144-152. doi:10.1016/j. jdevec0.2008.10.005

Hazans, M. (2003). Determinants of Inter-Regional Migration in the Baltic Countries. SSRN Electronic Journal,doi:10.2139/ssrn.742184

Hazans, M., \& Philips, K. (2009). The Post-Enlargement Migration Experience in the Baltic Labor Markets. In M. Kahanec \& K.F. Zimmermann (Eds.), EU Labor Markets After Post-Enlargement Migration. (pp. 255-304). Berlin, Heidelberg: Springer Nature. doi:10.1007/978-3-642-02242-5_10

International Monetary Fund. (2015). eLibrary Data. Balance of Payments Statistics. Available at: http:// elibrary-data.imf.org/DataReport.aspx?c $=7183654$ $\& d=33061 \& e=170784$. 
Jędrzejowska-Schiffauer, I., \& Schiffauer, P. (2017). New constraints on mobility in Europe: Policy response to European crises or constitutional ambiguity? Journal of International Studies, 10(3), 9-23. doi:10.14254/2071-8330.2017/10-3/1

Kaczmarczyk, P., \& Okólski, M. (2008). Economic impacts of migration on Poland and the Baltic states. Oslo: Fafo Institute for Labor and Social Research.

Kahanec, M., \& Zimmermann, K.F. (2011). The PostEnlargement Migration Experience in the Baltic Labor Market. Budapest, Hungary: Central European University; Bratislava, Slovakia: Institute for the Study of Labor (IZA), CELSI; Bonn, Germany: Bonn University.

Kahanec, M., \& Zaiceva, A. (2009). Labor market outcomes of immigrants and non-citizens in the EU. International Journal of Manpower, 30(1/2), 97115. doi:10.1108/01437720910948429

Kahanec, M., Zaiceva, A., \& Zimmermann, K.F. (2009). Lessons from Migration after EU Enlargement. In M. Kahanec \& K.F. Zimmermann (Eds.), EU Labor Markets After Post-Enlargement Migration. (pp. 3-45). Berlin, Heidelberg: Springer Nature. doi:10.1007/978-3-642-02242-5_1

Klicek, S., \& Loncar, J. (2016). Analysis of migration trends and functions of areas inhabited by Roma: Example of Medjimurje county (Croatia) and the settlement of Kursanec. Geographica Pannonica, 20(4), 227-241. doi:10.5937/geopan1604227k

Levitt, P. (1998). Social Remittances: Migration Driven Local-Level Forms of Cultural Diffusion. International Migration Review, 32(4), 926. doi:10.2307/2547666

Martinez, C., Cummings, M.E., \& Vaaler, P.M. (2014). Economic Informality and the Venture Funding Impact of Migrant Remittances to Developing Countries. Journal of Business Venturing, doi:10.2139/ssrn.2500375

Massey, D.S. (2003). Patterns and processes of international migration in the 21st century. In Conference on African Migration in Comparative Perspective. Johannesburg, South Africa.

Massey, D.S., Arango, J., Hugo, G., Kouaouci, A., Pellegrino, A., \& Taylor, J.E. (1993). Theories of International Migration: A Review and Appraisal. Population and Development Review, 19(3), 431. doi:10.2307/2938462

Matuzeviciute, K., \& Butkus, M. (2016). Remittances, Development Level, and Long-Run Economic Growth. Economies, 4(4), 28. doi:10.339o/economies 4040028

Melnikas, B. (2008). Integration processes in the Baltic region: the new form of regional transformations in the European Union. Engineering economics, 6o(5).
Mikalauskiene, A., Streimikiene, D., Mazutaityte-Cepanoniene, E. (2017). Employers' Openness to Labour Immigrants. Economics and Sociology, 10(3), 25-45. doi:10.14254/2071-789X.2017/10-3/2

Mishra, U.S., Singhania, D. (2014). Contrasting the Levels of Poverty against the Burden of Poverty: An Indian Case. International Economics Letters, 3(2), 26-35.doi: 10.24984/iel.2014.3.2.1

Meyer, D., \& Shera, A. (2017). The impact of remittances on economic growth: An econometric model. EconomiA, 18(2), 147-155. doi:10.1016/j. econ.2016.06.001

OECD. (2006). International Migrant Remittances and their Role in Development. In International Migration Outlook, SOPEMI. Edition, Part III, pp. 139-161.

Paas, T., Eamets, R., Masso, J., \& Room, M. (2003). Labour Market Flexibility and Migration in the Baltic States: Macro Evidences. Working Paper Series, University of Tartu, Faculty of Economics \& Business Administration. doi:10.2139/ssrn.419902

Rapoport, H., \& Docquier, F. (2006). The economics of migrants' remittances. Handbook of the economics of giving, altruism and reciprocity, 2, 1135-1198. Amsterdam: North Holland.

Ratha, D. (2005). Workers' remittances: an important and stable source of external development finance. In Remittances: Development impact and future prospects, Economics Seminar Series. 19-51; Paper 9. Available at: http://repository.stcloudstate.edu/ econ_seminars/9.

Rausser, G., \& Strielkowski, W. (2013). International Labour Migration and Structural Channels: A Case Study of Ukrainian Working Migrants in the Czech Republic. Ekonomický časopis, 10, 1034-1052.

Sabia, J. (2015). Do minimum wages stimulate productivity and growth. IZA World of Labor, (221). http:// wol.iza.org/articles/do-minimum-wages-stimulate-productivity-and-growth.

Stojanov, R., Strielkowski, W., \& Drbohlav, D. (2011). Labour migration and remittances: current trends in times of economic recession. Geografie, 116(4); 375-400.

Strielkowski, W., \& Sanderson, M. (2013). Structural channels for Ukrainian labour migration in the Czech Republic. Trames. Journal of the Humanities and Social Sciences, 17(3), 313. doi:10.3176/tr.2013.3.06

Strielkowski, W., \& Weyskrabova, B. (2013). Ukrainian Labour Migration and Remittances in the Czech Republic. Tijdschrift voor economische en sociale geografie, 105(1), 30-45. doi:10.1111/tesg.12052

Streimikiene, D., Strielkowski, W., Bilan, Y., \& Mikalauskas, I. (2016). Energy dependency and sustainable regional development in the Baltic states: 
A review. Geographica Pannonica, 20(2), 79-87. doi:10.5937/geopan1602079s

Trošt, M., \& Bojnec, Š. (2016). Export-led growth: the case of the Slovenian and Estonian economies. Post-Communist Economies, 28(3), 373-383. do i:10.1080/14631377.2016.1184425

UNCTAD. (2015). FDI Statistics. http://unctad.org/en/ Pages/DIAE/FDI\%2oStatistics/FDI-Statistics.aspx.

World Bank. (2013). Migration and Remittance Flows in Europe and Central Asia: Recent Trends and Outlook (2013-2016). http://www.worldbank.org/ en/news/feature/2013/10/02/migration-and-remit- tance-flows-in-europe-and-central-asia-recenttrends-and-outlook-2013-2016.

World Bank. (2015). Migration and Remittances: Recent developments and outlook. Migration and Development Brief. http://www.worldbank.org/en/ topic/migrationremittancesdiasporaissues/brief/ migration-and-remittances-publications.

World Bank. (2016). Migration and Remittances Factbook, $3^{\text {rd }}$ edition. http: //siteresources.worldbank.org/INTPROSPECTS/Resources/334934-1199807908806/4549025-1450455807487/ Factbookpart1.pdf 